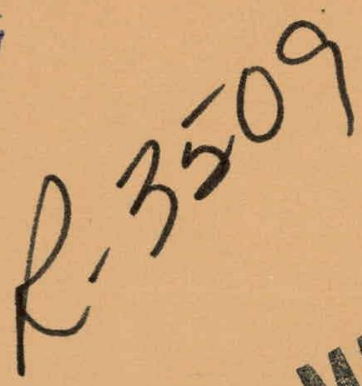

\title{
Labor Productivity in Heavy Construction: Impact on Synfuels Program Employment
}

\author{
K. C. Kusterer
}




\section{DISCLAIMER}

This report was prepared as an account of work sponsored by an agency of the United States Government. Neither the United States Government nor any agency Thereof, nor any of their employees, makes any warranty, express or implied, or assumes any legal liability or responsibility for the accuracy, completeness, or usefulness of any information, apparatus, product, or process disclosed, or represents that its use would not infringe privately owned rights. Reference herein to any specific commercial product, process, or service by trade name, trademark, manufacturer, or otherwise does not necessarily constitute or imply its endorsement, recommendation, or favoring by the United States Government or any agency thereof. The views and opinions of authors expressed herein do not necessarily state or reflect those of the United States Government or any agency thereof. 


\section{DISCLAIMER}

Portions of this document may be illegible in electronic image products. Images are produced from the best available original document. 
The facilities of Argonne National Laboratory are owned by the United States Government. Under the terms of a contract (W-31-109-Eng-38) among the U. S. Department of Energy, Argonne Universities Association and The University of Chicago, the University employs the staff and operates the Laboratory in accordance with policies and programs formulated, approved and reviewed by the Association.

\section{MEMBERS OF ARGONNE UNIVERSITIES ASSOCIATION}

The University of Arizona

Carnegie-Mellon University

Case Western Reserve University

The University of Chicago

University of Cincinnati

Illinois Institute of Technology

University of Illinois

Indiana University

The University of Iowa

Iowa State University
The University of Kansas

Kansas State University

Loyola University of Chicago

Marquette University

The University of Michigan

Michigan State University

University of Minnesota

University of Missouri

Northwestern University

University of Notre Dame
The Ohio State University

Ohio University

The Pennsylvania State University

Purdue University

Saint Louis University

Southern Illinois University

The University of Texas at Austin

Washington University

Wayne State University

The University of Wisconsin-Madison

\section{NOTICE}

This report was prepared as an account of work sponsored by an agency of the United States Government. Neither the United States Government or any agency thereof, nor any of their employees, make any warranty, express or implied, or assume any legal liability or responsibility for the accuracy, completeness, or usefulness of any information, apparatus, product, or process disclosed, or represent that its use would not infringe privately owned rights. Reference herein to any specific commercial product, process, or service by trade name, mark, manufacturer, or otherwise, does not necessarily constitute or imply its endorsement, recommendation, or favoring by the United States Government or any agency thereof. The views and opinions of authors expressed herein do not necessarily state or reflect those of the United States Government or any agency thereof.

Printed in the United States of America

Available from

National Technical Information Service

U. S. Department of Commerce

5285 Port Royal Road

Springfield, VA 22161

NTIS price codes

Printed copy: A03

Microfiche copy: A01 
Distribution Category:

Coal Conversion and UtilizationEnvironmental Protection, Waste Utilization, and Safety (UC-90j)

ANL/AA-24

ARGONNE NATIONAL LABORATORY

9700 South Cass Avenue

Argonne, Illinois 60439

LABOR PRODUCTIVITY IN HEAVY CONSTRUCTION:

IMPACT ON SYNFUELS PROGRAM EMPLOYMENT

by

Kenneth C. Kusterer

Department of Sociology

American University

Washingt on, D.C.

prepared for

Energy and Environmental Systems Division

Integrated Assessments and Policy Evaluations Group

Under Contract'31-109-38-5112

June 1980

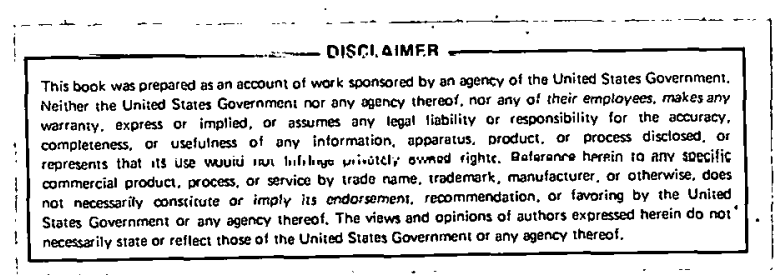

sponsored by

U.S. DEPARTMENT OF ENERGY

Assistant Secretary for Environment

Office of Finvironmental. Assessments

Regional Impacts Division 


\section{THIS PAGE \\ WAS INTENTIONALLY \\ LEFT BLANK}


CONTENTS

EXECUTIVE SUMMARY . . . . . . . . . . . . . . . . . . . . . . . . . . v

ABSTRACT. . . . . . . . . . . . . . . . . . . . . . 1

1 INTRODUCTION . . . . . . . . . . . . . . . . . . . . . . 1

2 RESEARCH APPROACH AND METHODS. . . . . . . . . . . . . . . . . . . 3

3 CONSTRUCTION LABOR PRODUCTIVITY: CONCEPTS AND MEASUREMENT . . . . . . 5

3.1 Definitions of Construction Labor Input . . . . . . . . . . . . . 5

3.2 Definitions of Construction Output. . . . . . . . . . . . . . 7

3.3 The "Deflators Problem" in Construction . . . . . . . . . . 8

4 HEAVY CONSTRUCTION: ORGANIZATIONAL FORMS, MANAGEMENT PRACTICES,

AND PRODUCTIVITY . . . . . . . . . . . . . . . . . . . . . . . 10

5 HEAVY CONSTRUCTION: UNION PRACTICES . . . . . . . . . . . . . . . . . 14

5.1 Background: The Open Shop vs. Union Shop Controversy . . . . . . 14

5.2 Evaluating Claimed Differences between. Union and Nonunion Productivity. . . . . . . . . . . . . . . . . . . . 16

5.3 Hiring Practices. . . . . . . . . . . . . . . . . . 16

5.4 Wages and Incentives. . . . . . . . . . . . . . . . . 17

5.5 Production Flexibility. . . . . . . . . . . . . . . . 18

5.6 Managerial Freedom. . . . . . . . . . . . . . . . . . . 19

5.7 Difference in Levels of Worker Skills . . . . . . . . . . . . . 19

6 HEAVY CONSTRUCTION: PRODUCTIVITY IN ECONOMIC AND REGULATORY

CONTEXTS . . . . . . . . . . . . . . . . . . . . . . . . 20

6.1 The Economic Context. . . . . . . . . . . . . . . . . . . 20

6.2 The Regulatory Context. . . . . . . . . . . . . . . . . 21

7 POPULATION CHARACTERISTICS AND REGIONAL DIFFERENCES IN HEAVY

CONSTRUCTION PRODUCTIVTTY. . . . . . . . . . . . . . . . . . . . 23

8 PRODUCTIVITY IN BOOM TOWN CONSTRUCTION SITES . . . . . . . . . . . . . 26

REFERENCES. . . . . . . . . . . . . . . . . . . . . . . . . . 29

BIBLIOGRAPHY. . . . . . . . . . . . . . . . . . . . . . 30

ACKNOWLEDGMENTS . . . . . . . . . . . . . . . . . . . . . . . . . . 34 
THIS PAGE

WAS INTENTIONALLY

LEFT BLANK 
Defining and Measuring Construction Productivity

Productivity is an apparently precise yet scientifically elusive concept, especially so in unique-product economic sectors like heavy construction. The proper concept for the purposes of this study is "labor productivity" - an older and conceptually simpler measure than "all factor productivity," the one currently more fashionable among economists. Labor productivity refers to the value added to the output product per time unit of labor input.

Standardized measures of productivity in heavy construction have yet to be developed. Key measurement problems include the lack of a standardized cross-project indicator of output, given the unique nature of each heavy construction contract. Within each product category, such as oil refineries or power generation plants, qualitative technological improvements are so large that the problem of conceptualizing quality "deflators" to standardize the product for comparative purposes has so far proven insoluble.

As a result of this inadequate conceptual validity, interstudy reliability of productivity measures is nonexistent. For instance, the U.S. Department of Commerce reports a decline in construction productivity of over $25 \%$ since 1967 , whereas Department of Labor research into specific construction product areas has consistently shown a steady increase, averaging more than $10 \%$ over similar periods. Two recent large-scale studies comparing union and nonunion labor productivity, both reasonably careful given the state of the conceptual development in this field, respectively conclude that union labor is $29 \%$ more productive than nonunion labor, 1 and that there is no significant difference between the two. 2

Variability of Productivity in Construction

Despite the difficulties of quantitative verification of productivity differences, knowledgeable industry experts (representing construction management, labor, clients, and private sector and government researchers) were in unanimous agreement that labor productivity varies from contract to contract over an extraordinarily wide range, as much so in large-scale heavy construction as in any other sector of the industry.

In the open-ended portions of interviews, construction managers, client managers, union leaders, and productivity consultants all identified various aspects of construction-project management practices as the main source of these productivity differences among projects. The issues of next highest salience in their thoughts on productivity were the quality and availability of skilled labor, but even management representatives agreed that this had a less significant impact on labor productivity than did management practices. 
$\underline{\text { Regional Variations in Productivity }}$

Rural-urban and boom-town growth effects on productivity had a low importance for the experts interviewed, and while all agreed that these factors "probably" have an impact on labor productivity, their discussions of these issues were frankly conjectural and speculative. Few felt themselves knowledgeable enough to speak to these issues "on the record."

Nevertheless, from their comments and from the limited literature on these topics, it is possible to conclude tentatively that (all other things, particularly management practices and the state of labor relations on the project, being equal) labor productivity is most likely to be highest on a small city/local labor project, lower on a big city/local labor project, and much lower on a small town/imported labor ("boom town") project.

Much of the increased labor time necessary because of lowered productivity in construction projects under boom town conditions takes the form of more overtime work rather than more workers employed, because such boom town projects have chronic difficulties in attracting and retaining a sufficiently large labor force. As a result, total employment will not be affected as much as the probably very large productivity differences might suggest.

Regional differences in labor productivity had a high salience for those interviewed. The topic was one of unexpectedly high sensitivity in the industry. No union spokesmen were willing to discuss the issue "for the record," expressing fear of internal union repercussions should their comments appear in print in an official government research document. Management spokesmen were even more reticent, unwilling even to discuss this issue off the record, because of an expressed belief that such information was an important proprietary asset, one among other great advantages that nationwide general contractors accrued from their experience, and that to reveal it might possibly dull their firm's competitive edge.

Speaking in the most general terms, a few persons in the industry suggested or agreed that labor productivity is somewhat higher in "sun belt states," except for the more highly urbanized Pacific coast region. Translated into terms of Basic Economic Areas, this suggests somewhat higher productivity levels for BEAs 20-51, 117-146, and 161-163. The reasons suggested for the possibly higher productivity in these regions included: (1) weather; (2) cultural values and "work ethics" among the workforce; and (3) heavy competition between large union and nonunion general contractors in these areas.

Productivity on "Utility Work" Projects

Within the heavy construction sector of the industry, labor productivity is much lower on those projects subject to the "utility work" syndrome than on other projects. This syndrome is not much recognized in the literature but is universally known and discussed within the industry. "Utility work" is the construction workers' phrase describing a project in which: (1) the project is relatively unique and therefore hard to cost-estimate in advance; (2) the product quality is more carefully monitored and usually government- 
regulated; (3) the size of the project is larger and therefore more complex than other heavy construction projects; (4) contracts are for all these reasons "negotiated" (in other words, cost plus) rather than competitively bid; (5) monopoly or governmental clients are relatively less concerned with construction labor costs than with construction speed; and (6) construction management's material interests are served by the meeting of deadlines and quality guidelịnes but not served by any reduction in project costs: The key indicator that signals the probable presence of the "utility work" syndrome, negotiated contracts, made up $47 \%$ of all unionized heavy construction projects in 1979 .

It is a virtual certainty that all synthetic fuel construction projects will be subject to this "utility work" syndrome. Industry representatives' "guesstimates" of labor productivity on such projects ranged from $50 \%$ to $80 \%$ of labor productivity on other heavy construction projects. (Again, these estimates were all off the record; none were willing to see their names connected with a government document with such an explicit acknowledgement of the existence of the "utility work" syndrome.) The conservative rough estimate would be $70 \%$, a figure that is backed up by only the most impressionistic evidence but one that is nonetheless better than completely ignoring the effects of this syndrome.

\section{Productivity and Project Morale}

Among "utility work" syndrome projects, labor productivity is even lower when management and labor suffer from "morale problems," as management and union representatives call them, as a result of manifest local opposition to the project, injunctions and other litigation-caused delays, and indecisive or fluctuating regulatory requirements. These result in project delays, quality control standards much higher than normal on other jobs, and expensive project design changes that force some completed work to be modified or rebuilt. Nuclear power plants were universally cited in the interviews as examples of projects suffering from these "morale problems."

Where significant mid-project design changes are called for, labor inputs required may even double (in other words, labor productivity as defined in this report is reduced by $50 \%$ ). Without major redesigns, but with just the normal amount of delays for such projects, labor productivity is probably reduced by $10 \%$, a conservative estimate.

It is probable that such large-scale energy projects as synthetic fuels construction projects will suffer to some extent, though not as much as nuclear power construction projects, from the lower productivity that results from these labor and management morale problems.

\section{Productivity and the Economic Context}

Labor productivity in heavy construction is higher in periods of cyclical economic expansion (and low construction-labor unemployment) and lowest in periods of cyclical economic contraction. This is implied in gross macroeconomic statistics and explicitly affirmed in the microlevel sociological 
literature and in the interviews with industry representatives. Both management and workers change their work practices in ways that increase labor productivity when the construction labor market is imbalanced on the side of strong demand, and in ways that decrease labor productivity when an oversupply of labor is readily available. Aside from the "utility work" syndrome, the state of the local and national economy in the construction industry affects labor productivity in heavy construction more than any other single factor.

\section{Productivity on Union and Nonunion Projects}

Despite the immense current controversy over the relative productivity of union and nonunion labor, there is no-presently confirmed evidence suggesting productivity differences in favor of one mode of labor relations or the other. There is some evidence that the differences between union and nonunion firms that might affect productivity are much greater in small-scale light construction than in large-scale heavy construction.

The supervisory/skilled/unskilled labor ratios of general nonunion construction projects differ significantly from union norms. In general, union projects employ one supervisor and two apprentices for every ten skilled crafts workers, whereas nonunion projects employ five supervisors (including working "lead men") and nine "helpers" for every ten skilled craft workers. These are average ratios for all construction projects. In the largest-scale heavy construction projects, however, nonunion practices are much more similar to union norms, so that two supervisors and two or three helpers for every ten craft workers is a more reasonable estimate for nonunion, large-scale heavy construction. This is still a significant difference in supervisory/skilled/ unskilled labor ratios for crafts work. But most unskilled laborers on unionized projects are performing general maintenance and portering duties around the site (indirect labor), not acting as apprentices helping with direct construction work. Including these laborers in the skill mix for unionized work results in the following overall probable differences between union and nonunion skill mixes. For the same large-scale, heavy construction projects, nonunion firms are likely to employ the same number of skilled crafts workers (including those serving as extra supervisors and "lead men") as union firms, and $5 \%$, or at most $10 \%$, more unskilled workers. 
LABOR PRODUCTIVITY IN HEAVY CONSTRUCTION:

IMPACT ON SYNFUELS PROGRAM EMPLOYMENT

by

Kenneth C. Kusterér

ABSTRACT

This study focuses on variations in labor productivity in the heavy construction industry. Productivity is one of a number of factors likely to affect the speed and cost of constructing a synthetic fuels plant. The findings of this study are presented with reference to synthetic fuels plants, but they are relevant to other large energy facilities as well. The data were gathered through a detailed literature search and extensive in-depth interviews with consultants in heavy industrial construction, union officials, and management. In this manner the most important determinants of labor productivity were identified and ranked in terms of relative significance.

The type of project under construction is the most important factor affecting the productivity of heavy construction labor. Projects characterized by the "utility work" syndrome are large, complex, relatively unique, highly regulated, and have cost-plus contracts and tight deadlines. Such projects generally have lower-than-average levels of labor productivity. Labor productivity is also lowered by worker and management morale problems, due to delays and design changes, and by high levels of unemployment among construction workers. Finally, boom town conditions, caused by workers moving to live near large projects located in ruial arcas, also are 1 ikely to result in below-average labor productivity. Synthetic fuels plants are likely to have a number of these identified characteristics. Consequently, the findings suggest that labor productivity may well be a problem for the timely development of an economically competitive synthetic fuels industry.

\section{INTRODUCTION}

This report contains the results of a study of labor productivity in the heavy construction industry. Construction labor productivity affects the costs, time schedules, and reliability of the facility under construction. This study is limited, however, to the effects of construction labor productivity on the numbers of workers required to build the plant. The rumber of in-migrant workers and their dependents is one of the chief factors causing the undesirable social conditions found in boom towns. All else being 
equal, the greater the labor productivity, the fewer the in-migrant workers needed, and thus negative boom town impacts are lower. Thus information on the variation in labor productivity could make an immediate and direct contribution to our ability to predict -- and thus possibly mitigate -- boom town conditions.

The Social and Economic Assessment Model (SEAM) developed at Argonne National Laboratory uses employment estimates taken from engineers and construction firms to project probable worker in-migration and thus potential boom town impacts. The central question addressed in this report concerns the feasibility of attaining more accurate projections by adjusting these employment estimates to reflect regional or boom town productivity differences. This study leads to the conclusion that such adjustments to these projections are not feasible, at least at present.

Slightly less simplified versions of the report's specific conclusions are found in the Executive Summary. Section 2 contains a description of the research on which these conclusions are based. Section 3 describes the definitional. and conceptual difficulties that still plague the study of productivity in the heavy construction industry, and Sections 4 through 8 explore specific factors likely to affect productivity in large-scale energy project construction (management practices, labor relations, economic and regulatory contexts, demographic differences, and boom town conditions).

This study was conducted as part of a larger effort to estimate some of the probable impacts of synthetic fuels plants. Consequently, many of the questions addressed to informants were presented in the context of the construction of synthetic fuels plants. Except as noted, however, many of the findings reported here are generalizable to some degree to other large-scale energy projects. 


\section{RESEARCH APPROACH AND METHODS}

This report is the result of a research project conducted in a series of overlapping stages. The first and most fundamental stage was a review of the literature; seeking both general findings applicable to productivity in heavy construction and specific examples of research on this particular sector. The literature that specifically addresses itself to productivity divides itself into three areas: economic (definitional, methodological, conceptual, and Bureau of Labor Statistics-type empirical measurement studies); managerial (focused almost exclusively on single-organization productivity, how to assess and improve $i t$ ); and behavioral science studies of work (analyzing formal and informal. organizational structures, worker attitudes and behaviors, with an emphasis on issues. of work-life quality and productivity). All three of these literature areas were reviewed.

Despite the large number of studies that at least tangentially address productivity, there is little information specifically on productivity in construction, and even less on productivity in heavy construction. Much of what does exist is policy-oriented hand wringing. Productivity in construction has for a decade been perceived as an important "problem." Yet the most highly developed body of literature, that of the economists, has not very sucessfully addressed this "problem," because of difficulties of conceptualization and measurement described in the next section of this report. Despite the general paucity of literature on heavy construction productivity, a few good studies have been reported recently, most conspicuously that of Bourdon and Levitt, ${ }^{2}$ and such studies have heavily influenced the conclusions reported here.

To insure that no substantial piece of literature was inadvertently omitted from this review, all experts interviewed were asked if they knew of any good references, and the last five years of relevant indices were checked under a number of related subject headings.*.

Concurrently with the literature review, initial exploratory interviews were conducted with experts, from the Departments of Labor and Commerce and from academia, who are working in the field of construction industry studies.

A second phase of the research project involved a retreat to the office, to digest what had been learned, to formulate more specific research questions, to track down (not always successfully) governmental or other narrowly circulated research documents referred to in the literature or the interviews, and to prepare for interviews with industry representatives by means of background reading in trade periodicals (especially Engineering News Record, the "bible of the construction industry," but also Constructor, Construction Labor Report, Electrical World, Coal Age, and Chemical. Week).

*i.e., Business Periodicals Index, Social Science Index, Work-Related Abstracts, Public Affairs Information Service, Joumal of Economic Literature, occupational Index, and Michigan Index to Labor Union Periodical.s. 
In the third phase, interviews were conducted with a limited number of union representatives in the construction trades, construction management officials, and construction productivity consultants. These were "specialized interviews" 3 in which the interviewer assumes that the expert knows so much more about the topic that the interviewee should have considerable freedom to define the specific issues discussed. Normally, such an interview would begin with a brief description of this research project and then the expert interviewed, would be given free rein to decide what information was most relevant. Only after this initial "open-ended" phase of the interview. had occurred were specific questions asked, most of them seeking clarification or verification of previous statements by the interviewee.

Depending on the circumstances, inclinations, and availability of the experts, these interviews were conducted either in person or by phone. They rariged in length frow ten minutes (by phone) up to a half day. Generally speaking, the longer the interview, the greater the rapport, the deeper the coverage of specific topics, and the more possible it berame, therofora, to break through the initial barriere of glib geneializations and public relations concerns. For these reasons, a conscious decision was made to use scarce researcher time in a smaller number of longer face-to-face interviews, $r$ ather than in a larger array of more superficial telephone contacts.

In the fourth stage of the projects, initial tentative conclusions and recommendations were written up, circulated among interested personnel involved in the analysis of community impact of synfuel construction projects, and discussed with a few of the informants whose interviews had proven most fruitful. Finally, some small modifications were made to these tentative findings, and the final report was written. 


\section{CONSTRUCTION LABOR PRODUCTIVITY: CONCEPTS AND MEASUREMENT}

Few concepts, ostensibly measurable, are subject to as many different definitions and interpretations as the term productivity; yet few terms are so often used as if a precise definition existed. (Ruch and Hershauer, Ref. 4, p. 13)

At the most basic and general level, productivity refers simply to the concept of efficiency: the ratio of inputs to outputs. Even this general definition, however, is not universally accepted. Management personnel and managerial literature tend to use the term productivity to mean nothing more specific than general effectiveness in meeting organizational goals. 5 There is, therefore, a broad gap between managerial discussions of productivity, in the context of single-firm attempts to improve the firm's performance, and economists' conceptual and technical studies. Given the purposes of this inquiry, productivity must be used in the more restricted sense of input/ output ratios, rather than general work effectiveness.

Accepting the basic input/output-ratio concept of productivity is merely the first step into definitional difficulties, however; it merely. enters into the unresolved technical economic debates over the conceptualization and operationalization of both inputs and outputs. Economists generally hold out the ideal of one day being able to measure operationally the productivity of an economic sector or an industry, with each production factor measured separately and then summed to form a measure of total input. Factor productivity refers to a ratio of a specific type of input to total output: output per unit of capital invested, per unit. of fixed capital, per unit of raw material, or per unit of labor time. This last concept, output per unit of labor time input, is referred to as labor productivity, which is the oldest and most researched of the specialized sector productivity concepts. This idea is so well established that references to "productivity" in the literature often refer actually to the more restricted concept of labor productivity. Since the basic purpose of this report is to analyze the effects that productivity variations might have on the amount of labor required for construction of large-scale energy projects, labor productivity is the appropriate concept.

\subsection{DEFINITIONS OF CONSTRUCTION LABOR INPUT}

Accepting the definition of productivity as labor productivity for the purposes of this report opens the issue of inclusivity. Whose labor time is to be counted in operational versions of the concept? Here, again, the dominant tendency among economists is to strive for a definition as inclusive as possible. One surprised construction union official, interviewed shortly after attending a national conference on construction productivity sponsored by the National. Academy of Sciences, was still shaking his head in disbelief: "They want to start with the guy who cut down the tree -- no, the guy who planted it -- and take in everybody from there on up. No wonder nobody knows anything about productivity in construction ..., it's too impractical." From the economists' point of view, however, it is difficult to discover any way of insuring reliability and comparability of single-industry statistics unless they count all labor time. Otherwise, variations from one firm or 
construction project to another in terms of production organization (extent of vertical integration) or in production technology (on-site fabrication versus off-site prefabrication) would so drastically change the labor input measurements as to invalidate any productivity, comparisons. The construction labor productivity statistics of, for example, the Division of Technological Studies of the Bureau of Labor Statistics thus include both on-site construction labor and off-site labor necessary to process natural resources into the construction materials used on the site.

Since the ultimate purpose of this report is to help assess the impact of large-scale energy construction projects on their surrounding communities, only the productivity of on-site labor will be discussed. In other wordo, the technological chuices in construction design that allocate necessary labor to off-site prefabrication or to on-site construction are placed, for the purposes of this study, into the ceteris paribus category of background variables. Of course, nothing has a greater significance for labor productivity in general than the type and level of technology available; but cechnology is not among the factors whose effects on construction 1abor productivity fall, within the scope of this report. Therefore, this report makes the necessary although tenuous assumption that for each type of large-scale energy project there exists a more or less standard mode of best-available construction technology, one that would be chosen regardless of the social and demographic characteristics of the particular project's surrounding area or potential labor force.

The choice of on-site labor as the defining category of labor input does greatly simplify one other definitional problem that normally complicates 1 abor productivity measurement studies. The normal convention is to include direct labor (i.e., actual production work) and indirect labor (e.g., maintenance, material handling, set-up, inspection, quality control, and direct line supervision) as labor inputs, but to exclude overhead activities (e.g., purchasing, payroll, personnel, sales, development engineering). This normally causes difficulties of allocating white-collar time between indirect and overhead activities. But in the construction industry, the line between indirect and overhead activities very closely approximates the division between on-site field office personnel and those back in the company offices. On-site location as a criterion for inclusion in labor time calculations thus fortuitously includes both direct and indirect labor while effectively excluding overhead activities.

No attempt is made here to treat labor time inputs in terms of "weighted" values of labor. Such attempts to quantify qualitative distinctions among types of laborers are completely impractical, given the present state of conceptualization and statistical measurement in the field. Economists who do calculate weighted-labor inputs can do so only by making use of wage-based weights, a practice that assumes that wage differentials directly reflect real differences in the quality and productivity of labor, or in other words, a labor market based on perfect competition and perfect competition only. Such an assumption leads some economists who have written on productivity to blandly make statements such as the following: 
When one kind of $l$ abor is more productive than another kind, it will be more valuable. And when it is worth more, it will generally earn more. In fact, we can measure the quality of an hour of labor by its price in earnings, which tend to equal its value in production in a competitive market... (Ref. 6, p.44).

Over the last fifty years or so ..., adult females earned about 50 to 70 percent of the adult male wage. The reasons are pretty clear... Most women do not stick with an occupation long enough to reach the level of experience of 'men. Experience is not all the story, but more detailed analysis indicates that the differences in earnings correspond reasonably well with differences in quality: (Ref. 6, p.48).

Women (and minorities) would undoubtedly reject such economists' assumptions as unnecessary insult added to the injury of wage discrimination. But the same domain assumptions of neoclassical economics -- that price in a competitive market reflects only utilitarian rationality, and that the present-day American economy is sufficiently competitive for such utilitybased prices to prevail -- lead productivity economists to conceptualize construction output in a way that seems just as outrageous to some in the construction industry.

\subsection{DEFINITIONS OF CONSTRUCTION OUTPUT}

Economists interested in intersectoral analyses of productivity can compare apples and oranges only if they first convert the apples and oranges into a standard unit of value, usually dollars (or more precisely, baseperiod "constant" dollars, to eliminate the effects of inflation). Only by measuring output in dollar terms, instead of by product-specific measures such as bushels of wheat or square feet of office space, is it possible to sum outputs or compare productivity ratios. In the heavy construction industry, economists find the dollar value of gross output by looking at total construction price, the cost to the client of the project. Logically, the only possible market value of a heavy construction project's unique product is the price the client actually paid. Unfortunately, half of all heavy construction projects (in 1979) and almost all of the largest projects are constructed on the basis of "negotiated" (cost-plus) contracts, rather than on the basis of competitive bids. On a cost-plus project, every dollar's worth of wasted material, underutilized equipment, and unnecessary labor time is directly and automatically transformed into a "dollar-plus" worth of output, thus rendering nonsensical any productivity measures based on such a conceptualization of output. Within the construction industry, experts interviewed were either amused (mostly union representatives) or angered (the uniform management reaction) by economists and productivity analysts who so persistently use this approach to the measurement of construction productivity.

Louis Alfeld, former head of the construction section of the National Productivity Commission and now a leading consultant in the field of construction industry productivity, urges that construction output be measured not in terms of simple market value, but in terms of some dollar value more 
tightly linked to the marginal utility (to the client's own production) of the constructed plant. Productivity, for instance, in energy industry construction projects, might be calculated in terms of a ratio between labor time input and a standard unit of constructed energy-production capacity (BTU, barrel of oil equivalents, or other possibly more appropriate but less-known measures). As a second stage in the analysis, a dollar value might be placed on standard units of constructed energy-plant capacity, but even if this second stage is not feasible, such use-value-based output measures can at least permit meaningful comparisons of construction labor productivity among energy construction projects. The Edison Electrical Institute, the trade association of the electric-power generating industry, has already developed the methodological capability to measure power plant construction productivity in terms of labor time inputs per megawatt of constructed generation capacity, but the results of these productivity calculations are available only to the Institute's member firms, not to other researchers or the general public.

\subsection{THE "DEFLATORS PROBLEM" IN CONSTRUCTION}

The standard method for time-series productivity comparisons within a single industry requires adjusting the more recent output figures by subtracting the value of qualitative improvements in the nature of goods or services produced. This is done to ensure that the later studies are strictly comparable (in terms of the nature of the output) to the earliest study. These quality adjustments, called "deflators," effectively hold constant the value of the output so that valid productivity comparisons can be made. Conceptually, deflators hold the value of the product constant in the same way that base-year "constant dollars" hold prices constant for many other kinds of economic time-series comparisons.

Though always technically difficult to operationalize in any industry, the conceptualization of deflators in mature-product, mass-production industries is relatively simple. If refrigerators have increased in value because they now incorporate automatic defrosting features, or typewriters because they now correct themselves, the value that these new features add to their products can be determined, and the output of the two industries can be adjusted proportionally. Outside the world of mass-production, however, the problem becomes conceptually much more difficult. When each product differs because each is custom-made to a client's specifications, then there is no simple adjustment possible to hold output quality constant. In construction (and hundreds of other industries in both the manufacturing and service seclurs of the economy), each product is relatively unique, and quality differences from one product to the next are normative and inherent in the nature of the industry. Productivity comparisons in such industries require careful calculations of product $\mathrm{mix}$ and quality averages before even the conceptualization of a quality deflator is possible.

For these reasons, the deflators used in construction productivity analyses, when available at all, are surrounded by controversy over their validity. Only in the most mass-production-like sectors of the industry, such as highway construction or large-scale residential building, have they even been attempted. And even in those sectors, the deflators that have been suggested, to adjust highway construction figures for the improved 
corrosion resistance of newer formulas for concrete or to adjust residential construction figures for the additional square footage of present-day houses, can claim to account for only a small part of quality differences.

Since this study does not make time-series comparisons of 1 argescale energy construction projects, the difficulty of deflator conceptualization does not directly arise. But the impact of the "deflator problem" on the study is nevertheless quite significant, because it is this difficulty that has prevented the Bureau of Labor Statistics (or private firms that publish construction statistics) from developing and publishing standardized productivity figures for the construction industry. Comparing regional differences in heavy construction productivity, like any other topic that uses heavy construction productivity as either an independent or a dependent variable, cannot be a matter of comparative analysis of any avai1able or generally accepted statistics. Such statistics have yet to be developed, because fundamental conceptual diffficulties are still unresolved. Some productivity figures do exist, but they are either discounted by their own producers, as is the case of the Bureau of Labor Statistics' figures, or they are intensely disputed by other researchers, as is the case with Allen's recent research on unionized labor productivity. 1

Given this state of knowledge in the field, the best research this study can report is definitional and conceptual. Aspects of construction labor productivity that are readily apparent to knowledgeable people. in the industry, productivity differences so great that they $c$ an be qualitatively perceived even in the absence of quantitative measurement, and knowledgeable judgements about the implications of only partially applicable data account for, unfortunately, the state of the art of construction productivity research.

But to achieve even this level of scientific precision, a careful and rigorous definition and use of productivity concepts is necessary. It has been the purpose of this section to arrive at such a definition. Therefore, as stated earlier: given the focus of this study, the most appropriate productivity concept refers to the ratio of output (conceptualized in use value rather than market value terms) to unweighted on-site labor time input. In other words, productivity is the ratio of the time the construction workers put into the project to the energy-producing capacity of the finished facility they produce. 
4 HEAVY CONSTRUCTION: ORGANIZATIONAL FORMS, MANAGEMENT PRACTICES, AND PRODUCTIVITY

When productivity in heavy construction is assessed, management emerges as the key variable. This is the unanimous belief, held by every person interviewed, and, in part, this is a simple affirmation of standard American business ideology. The reasoning is as follows: productivity is the result of production decisions; production decisions are the responsibility of management; productivity is the result of management's exercise of that responsibility. In part, this focus on management reflects the informants' experience that managerial competence varies from manager to manager and organization to organization over a very wide range. Productivity is the cumulative result of a million mundane administrative details of equipment availability, material delivery, and work scheduling over the life of a project. Some managements stay ahead of these details most of the time and administer them effectively and others don't.

The most important reason for the emphasis on management's role in productivity, however, is the insider's knowledge of how close to the margin of managerial control is the normal operation of a huge construction project. From ground-breadking to ribbon-cutting, the task of managing a large heavy construction project lasts up to ten years or more. The size and scope of that which is to be managed is awesome, even to an experienced construction manager. Such large projects take so long to complete in comparison to a human career span that members of the top management team of a very large project would be unlikely to have experienced comparable responsibilities on more than a couple of such projects in their previous careers. Yet the complexity of the project to be managed is more awesome than its size, involving dozens of different trades, each working independently but each totally dependent on the work of others; and thousands of distinct tasks, each with its own set of detailed blueprints but each also dependent on the correct and timely completion of a hundred other tasks.

The larger and more complex the project, the more distinctive it is likely to be. So, at the same time as the job of management gets harder, the proportion of the job that permits the direct application of previous experience declines. Sidewalks, streets, and townhouses can be very much alike; the very largest factories, skyscrapers, and processing plants cannot. Everybody who goes to work on a new large-scale heavy construction project, therefore, is starting all over, at least to some extent, on a new learning curve.

Without romanticizing or exaggerating the difficulties, it is nevertheless necessary to recognize the almost unique problems of heavy construction management, in order to understand the industry's unusual organizational and managerial patterns and to understand the effects of these adaptive patterns on productivity. The nature of the construction task is such that managers approach their task more like managers in other production sectors would approach a new pilot production project rather than another year of ongoing and relatively routine mass production. Construction managers concentrate on two goals only: meeting the construction specifications and quality standards, and meeting the construction schedule'. It is a struggle to get the job done at all; it is managerial excellence to get the 
job done right and done on time. To get the job done right, on time, and also in the most efficient possible way is not something that construction management has traditionally striven for. Construction productivity consultant Louis Alfeld put it this way in an interview:

It's crisis management, pure and simple -- a wartime mentality, really. Traditionally, nobody has thought in productivity terms. What matters is getting something done .... The emphasis in management has not been on productivity, it has been on getting something done and done right.

Organizational forms in the construction industry support and reinforce these somewhat unusual managerial values, so that "getting something done and done right" becomes the consensual task definition, the shared meaning of work, in the entire industry, as much for the workers and even the clients as for the management.

What is the point of view of the client? On commercial construction projects, clients are making a huge investment of fixed capital, which cannot start earning a return on this investment until the construction is complete and the facility $c$ an be put into operation. A client's overriding concern is usually to speed completion of the project, to minimize the time until that investment starts earning. Almost always, construction financing is shorter-term and costs more than the operating-capital financial arrangements that can be set up once the facility is finished and physically avai1able to serve, if necessary, as collateral. So the financial structure of the construction debt increases the client's interest in rapid completion and absence of delays. To the client, any contractor errors on the side of labor underutilization and lowered labor productivity are likely to be financially insignificant compared to the cost of even a small delay in the project's completion. This is true even under the most disadvantageous (to the client) terms of a completely cost-plus contract. Because of this client perspective, construction contracts more often feature a system of bonuses and penalties to reinforce the deadlines than they do any system of incentives for the contractor to reduce costs through increased productivity.

The larger, the more complex, and the more nearly unique the construction project, the more likely it is to be built on the basis of a costplus contract. Size, complexity, and uniqueness all contribute to the likelihood of unforeseen difficulties and so increase the project's risk. As a result, contractors are less willing to bid a fixed price for the job, or if they are willing to bid, the bid will have to be set high enough to cover all possible contingencies. One contractor explained:

Any experienced client will recognize that if he is going to force the contractor to take over all the risk, he is not going to get anything but unrealistically high prices on that job. He knows he will do better if he just agrees to pay the fair costs and lets the contractor get on with his job.

This is the basic rationale behind the prevalence of cost-plus contracts in heavy construction, especially at the largest end of the project scale. 
Though it is possible to modify a basic cost-plus contract to increase the incentives for reducing the project cost, such arrangements are not common in the construction industry. Normally, the contract merely calls for a third-party auditor, whose basic function is only. to check that reported costs were actually incurred. The common belief in the industry is that any additional, more complicated methods of allowing clients to monitor or control the contractor's practices will merely increase the possibility of legalistic delays, merely transfering client's costs from construction contractors and workers to lawyers and legal department personnel.

Since one of construction management's principal objectives is avoiding delays, and since heavy construction contracts so seldom serve as an incentive for reducing costs or increasing productivity, it is a standard management practice in the industry to "play it safe" in calculating labor requirements. It is more important to malce oure enough people are available in each uf the trades to avoid a costly bottleneck, than it is to plan each task finely to avoid the underutilization of available labor. In every other industry, unions and managements fight over worker productivity in the following way: the management wants to reduce costs, so it wants to see fewer workers; the union wants to avoid "speed-up," so.it wants to prevent layoffs. In the construction industry, the argument is inverted: management insists that more workers are necessary and the union must supply them, while the union insists that whatever lesser number of craftworkers it is able to provide is sufficient to do the job.

According to all but one of the union representatives interviewed and all of the actual contractors interviewed (but not their more publicrelations-oriented spokespeople in either the trade associations or the AFL-CIO headquarters), this practice of management, whether it is evaluated as payroll padding or prudent insurance to avoid much more costly project delay, is the principal factor affecting labor productivity in the heavy construction industry. In effect, the claim is that management consistently attempts to reduce labor productivity, and it is constrained in its efforts only by occasional circumstances outside its control, such as an undersupply of labor in a particular craft due to either a general economic boom in construction or union reluctance to imperil its future labor monopoly by taking in more members.

This perspective of the client and the management sets the background for the prevalence in heavy construction projects of what workers in the industry refer to as "utility work." Utility work differs from other largescale construction jobs only in the degree of unconcern with labor productivity. I'he name apparently originated in reference to public utility construction projects and is now applied as well to most government projects. On a utility work project, the propensity towards an ample supply of labor in each trade is coupled to a relative unconcern with the urgency of deadlines, either because the client is not a profit-oriented organization or because the client's rate of profit is more or less fixed by regulatory commissions. In the latter case, even the client may be operating under the same motivating conditions as the contractor with the cost-plus contract. If profits are set as a fair rate of return on investment, then higher cost may mean equivalently higher profits. This analysis of the probable cause of the "utility work" syndrome would of course require much more rigorous investigation to achieve more than a hypothetical status, but 
the existence of the syndrome, familiar as it is to all in the industry, can be confidently asserted.

Within the industry, however, there is a clear line between a utility work project on which the construction progresses, though perhaps slower than need be, and a project whose participants begin to experience it as a "utility work" project, on which progress seems to have broken down altogether. These latter projects suffer, as all informants euphemistically phrased it, from "morale problems," because the sense of deadline-beating urgency that is so central to the industry's definition of the meaning of its work has disappeared completely. This occurs when circumstances that the project's construction managers and workers interpret as totally outside their control -- confused or changing regulatory requirements and repeated design changes being the two most cited examples -- repeatedly delay a project, or even reverse it so that previously completed work must be dismantled or rebuilt.

These delays are so demoralizing because the race against a deadline is a central feature of the constuction industry's value system and task definition. When the client, the government inspectors, and even the surrounding community seem not to care much when, if ever, the project is completed, this value system is thoroughly undermined, and productivity declines dramatically, even from the utility work standard that might have previously prevailed on the project. These morale problems were salient for every industry spokesperson interviewed. When asked to talk of productivity, each referred to this type of a bedeviled project, and each characterized nuclear power plant construction projects as presently being overwhelmed by these sorts of problems. Everyone in the industry who is asked to discuss construction productivity in the synfuels program immediately expresses the concern that synfuels projects might not be able to escape the nuclear construction sector's "morale problems," no matter how different the enabling legislation or how strong the leadership of the Department of Energy.

Given the conflicting interest groups vitally affected by the synfuels program, perhaps the anxiety expressed by the interviewees is indeed realistic. In any case, their characterization of the synfuels projects as prime candidates meeting all the conditions for activating the "utility work syndrome" is certainly realistic. Within the present range of heavy construction labor productivity, synfuels project productivity will likely be near the low end of the spectrum. Experts who allowed themselves to be pinned down to a percentage comparison of labor productivity in utility work and in other heavy construction -- all of them, incidentally, on the management side -- speculated that utility work figures would range from $50 \%$ to $75 \%$ of labor productivity on other projects. Attempting to check these figures against the Bureau of Labor Statistics' studies for particular heavy construction projects, for instance, federal highways and college dormitories, proved fruitless because most of the labor in the BLS studies is 1 abor carried out offsite, and, in fact, in construction-materials manufacturing industries outside of the construction sector altogether. The difference between this study's definition of labor productivity and the definition used in the BLS studies is so great as to make meaningful comparison conceptually impossible. Hard figures, reliable or not, on the effects of the utility work syndrome are not available anywhere, since the syndrome is heretofore unacknowledged in academic and technical literature on the subject (except for the ethnographic participant-observation studies, like those of Cherry, Lasson, LeMasters, and MacKenzie, 7-10 which do not, however, focus explicitly on that issue). 


\section{HEAVY CONSTRUCTION: UNION PRACTICES}

From the sound and fury of the dispute, the constant lobbying and agitation, the open shop claims and the union shop defenses, the outside observer could be pardoned for believing that the heavy construction industry's labor relations and idiosyncratic forms of unionization would be one of the key issue areas within which labor productivity effects would be found. The general conclusion of this research -- a conclusion that surprised even the researcher - is that the effect of union-related variables on labor productivity in the heavy construction sector of the industry is probably nil. This is also the conclusion of Bourdin's and I.evitt's eight-city, HuD-financed study. of the effects of unions on earnings and labor relations practices. It disagrees with Allen's recent study, 1 which found union labor $29 \%$ more productive, but Allen's study, though carefully designed and carried out, did not successfully avoid the pitfalls of output measurement in market price terms (See Sec. 3) or of differences in size and scale between the unionized sector and the nonunionized sector.

\subsection{BACKGROUND: THE OPEN SHOP VS. UNION SHOP CONTROVERSY}

In the 1960s, after a prolonged construction boom during which unions were unable or unwilling to supply sufficient quantities of sufficiently skilled labor, and during which an ever-increasing proportion of national construction activity was taking place in the traditionally nonunion areas of the sun belt, nonunion contractors initiated a new offensive in their longcontinuing campaign to break the hold of unions over large-scale contract construction. Organized into the Association of Building Contractors ( $A B C$ ), their upstart campaign against both unions and the union-shop Association of General Contractors (AGC) met with unprecedented initial success and even more success later in the $1970 \mathrm{~s}$, as contract construction entered into a prolonged slump after 1968 and again in 1974. As both a contributing factor to, and a beneficiary of, this open-shop drive, there now exist a handful of nationallevel, large-scale general contractors within the open shop movement. More than at any time since the 1930s, it has now become possible for the largest construction projects, like those contemplated in the synfuels program, to be carried out entirely by open-shop general contractors and subcontractors.

In 1976, the proportion of construction that was nonunion had reached the following percentages in the eight metropolitan areas. sampled by Bourdin and Lcvitt:

$\begin{array}{lllr}\text { Atlanta } & 26 \% & \text { Grand Rapids } & 20 \% \\ \text { Balt imore } & 46 \% & \text { Kansas City } & 1 \% \\ \text { Boston } & 12 \% & \text { New Orleans } & 36 \% \\ \text { Denver } & 30 \% & \text { Portland, Ore. } & 10 \%\end{array}$

The most recent Current Population Survey puts the percentage of "foremen, craftsmen, and kindred" involved in al1 types of construction at $38 \%$ union, $62 \%$ nonunion. The $A B C$ claims that $55 \%$ of all construction contracts were held by nonunion firms in 1979, and the AGC claims that $74 \%$ of all heavy 
construction projects were contracted to union firms in the same year. The most appropriate figure for the purposes of this study would be the percentage of contract dollars awarded in heavy construction to union and nonunion firms, but such data is unavailable even from such probably biased sources as the $A B C$ and the AGC. Overall, however, there does not appear to be too great a conflict between the $A B C^{\prime}$ 's claim of $55 \%$ of all construction contracts being nonunion and the $\mathrm{AGC}^{\prime} \mathrm{s}$ claim that in the largest-scale heavy construction sector of the industry the nonunion percentage of contracts was $26 \%$.

Spẹaking in terms only of large-scale heavy construction requiring a nationally competitive general contractor's resources (in other words, projects large enough to attract bids, in the unlikely event that they are contracted. out through competitive bidding from all over the country), the percentage of contracts allocated to unionized contractors is probably 80-85\%. Only in the Gulf Coast and South Atlantic regions of the southern states is the proportion of union contracts in such very large-scale projects likely to be much lower than this national average, and only in some northern urban concentrations is it likely to be much higher.

As part of a union counteroffensive to this open-shop drive in construction, the building trades department of the AFL-CIO has pushed its member unions, who have in turn pushed their locals (despite the reputed power of labor autocrats, unions cannot act monolithically no matter how strong the threat), to substantially modify traditional union practices in a few key areas where the managerial and public outcry was strongest. Among these changes, two have probably had the greatest impact on productivity; they certainly have had the greatest impact on managerial discontent. On large construction projects, unions now routinely negotiate "project agreements," signed by management and all the unions on the project. These project agreements usually include no-strike pledges, modifications of obsolete work-rules in various trades, and plans for the avoidance of jurisdictional disputes in work tasks that have often engendered such disputes in the past. The second concession that unions have made has been to much more successfully avoid jurisdictional disputes, allowing to go unchallenged the informal arrangements that union workers and first-line supervisors (who are also usually unionized) have traditionally established. Both these changes can be attributed to the open-shop movement's success, and the construction unions' resulting perception that there are much more important "enemies" to contest than each other. The resulting cooperation among unions has-minimized work interruptions, permitted the tacit neglect of many of the more technologically obsolete work practices, and facilitated management's job of coordinating construction tasks.

These union responses to the open-shop challenge have been generally successful, at least in heavy construction! since the percentage of heavy construction contracts let to nonunion firms has leveled off since about 1972, after rising steadily in the eight years before that. Naturally, such changes have been put into most widespread practice only in the areas of the country like Baltimore, Denver, and Minneapolis, where union locals have most directly felt the open-shop pressure. In other areas of the country, the change has not been so noticeable, either because the union movement was never strong enough to develop such firm work rules (e.g., San Diego, New Orleans) or because union militancy had continued to be so strong that such adjustments have seemed locally unnecessary (e.g., Chicago, Wheeling). 


\subsection{EVALUATING CLAIMED DIFFERENCES BETWEEN UNION AND' NONUNION PRODUCTIVITY}

In the debate over the relative merits of their two systems, antiunion and pro-union advocates have made a number of claims about the differences between union and nonunion labor and the effects of these differences on construction productivity. The nonunion Association of Building Contractors emphasizes four areas where their practices differ from unionized firms: 1) recruitment and hiring practices; 2) wage and incentive systems; 3) organization of production and flexibility in the division of labor; and 4) managerial freedom to innovate. In response, the unions and the unionized contractors' association, the Association of General Contractors, claim a fifth area of difference, this one in their favor; 5) the greater skill levels and professionalism of union-trained workers.

\subsection{HIRING PRACTICES}

In a union shop, all hiring is formally done through a local union official's referral; in a nonunion shop, contracting management formally hires each worker directly.. In actual practice, the bulk of all recruitment and hiring, in either the union or nonunion sector, takes place through informal word-of-mouth networks. According to the two formal systems, management should be better able to avoid less productive workers when they don't need union referral, but in practice unionized construction management has no more or less problem finding and retaining the best workers than management in the nonunionized sector. So much rhetorical heat has been generated by the public debate over this issue that the actual insignificance of this difference, confirmed as it is by the participant observation literature, by all the managerial and union representative's interviews, and by Bourdin and Levitt's study, needs to be strongly emphasized, as it was by Bourdin and Levitt in. the summary of their. findings:

There are very few significant differences reported in hiring practices between different types of firms, either union or open shop. Union firms, both general and subcontractors, most o,ften hire by word of mouth through their foremen or present employees. When they do hire through a hiring hall, they often request journeymen by name, thus avoiding the personnel assignment function of the business agent. The exceptions to this "informal" approach to hiring come under two circumstances. First, when a large number of journeymen in a particular trade is needed for a project (and/or the project is in a different arca from the main office u[ llig firm), the union business agent or hiring hall plays the major role in recruitment and referral. These are found by contractors to be adequate mechanisms to assemble large crews quickly. The only problem is the variation in quality, particularly in times of peak demand. One contractor said that at times of low unemployment the hall can only furnish " "warm bodies" and not skilled journeymen. Second, in times of high unemployment in construction, the hiring hall is not needed. Men continually come to the offices or gates of projects looking for work and crews $c$ an be obtained through these men or through referrals by employed journeymen of friends who are not presently working. 
The methods used by open-shop contractors are similarly infurmal. Most men are hired by word of mouth through present employees. Some recruit directly from local vocational schools. others find that men come to the main office or gate. When larger numbers are needed, recruitment is supplemented by newspaper ads or by using the local employment service. As in the union sector, open-shop contractors also vary their recruitment strategies with the state of the labor market: in troughs, men come to them; in peaks; continual, aggressive efforts using all information channels are needed to find anyone remotely capable of construction work.

Since hiring occurs in a similar fashion in both union and openshop sides of the industry, the impact of the union can only be judged to be slight. (Ref. 2, p. 82)

\subsection{WAGES AND INCENTIVES}

All unionized workers are paid a predetermined union-scale wage. Nonunion workers are paid an individually adjusted, productivity determined wage. A small percentage of union workers and a slightly larger percentage of nonunion workers are paid according to a piece rate. This system, more directly linked to productivity, is supposed to serve as an unlimited incentive for maximum production but in fact only serves to insure that workers will produce a daily informal quota without the necessity of supervisory prodding.

Contractors who pay a fixed union rate are able to make only crude adjustments of labor costs to productivity by selective retention of the most productive workers. Large contractors are free to .organize their daily layoffs or re-hires so as to accomplish this purpose without any difficulty from the union. Nonunion contractors are able to adjust individual wage rates to individual productivity levels, but this theoretical capacity is. frequently limited by other circumstances. On labor-short projects, such contractors must pay at least the union scale to anyone worth retaining. That effectively raises the bottom limit of the pay range, and contractors understandably choose not to significantly raise the upper limits of the range in order to maintain their productivity-based individual differentials. In other words, the prevailing labor market conditions, which in heavy construction is union dominated, determine labor wage rates more than any management schemes of incentive-system management. Likewise, in times of readily available labor surplus, productivity incentives are relatively unnecessary, and the pay range is similarly contracted. "An additional factor that reduces management's incentives to construct and maintain finely tuned wage-differential incentive systems is the temporary nature of the employment relation between the company and any individual nonsupervisory employee.

In this area too, therefore, the apparent potential for significant productivity differences between the two sectors of the industry is much greatcr than the real differences. 


\subsection{PRODUCTION FLEXIBILITY}

The $A B C$ believes that it has finally ushered the construction industry into the era of modern managerial practices by introducing the same more efficient techniques of task disaggregation and work simplification that mass-production manufacturers have pursued at least since the $t$ ime of Frederick $W$. Taylor and his "scientific management" by efficiency engineering. $A B C$ firms recruit workers who are less generally skilled and train them in more specifically defined tasks. Such practices break down the traditional distinctions between crafts at the same time as they reduce the need for a more general training in all aspects of a trade.

As a result of this form of production organization, $A B C$ firms hire fewer skilled crafts workers and more "helpers," a work category unknown in the unionized sector of the industry. But they also require a much higher number of "leadmen" and "working foremen" to supervise the less-skilled work furce. These also are work categories unknown in union construclion, where foremen are union members but usually required by work rules not to do anything but supervise. A comparison of union and nonunion practices in the two sector's modal scales of operation is presented in the following table (Ref. 2, p. 70):

\begin{tabular}{lllll} 
& \multicolumn{1}{c}{ Supervisory } & More Skilled & Less Skilled \\
\cline { 2 - 2 } Union & 1 foreman & 10 journeymen & 2 apprentices \\
Nonunion & 5 leadmen/foremen & 10 journeymen & 9 helpers
\end{tabular}

The figures given in this table, however, must be adjusted to compare the two sectors' organizational practices in heavy construction. This is because the table is based on comparisons of the two sertors in their "ave= rage" operating firms: for nonunion construction this means residential building; for union construction it means medium-sized commercial construction. In moving to very large-scale heavy construction, the proportions of unionized labor categories do not change significantly, but the proportions of nonunionized labor do. The basic reason for this is that work rationalization and task simplification only improve efficiency and productivity for relatively routine and unvarying production operations. In the more nearly unique, more complex and more varied circumstances of the largest projects, the industry's traditional use of self-directing crafts workers with multiple skills is more rationall and is therefore also adopted by the nonunionized firms :

Among large open-shop contractors like Daniels and Brown and Root, jurisdictional lines and on-site work organization are very similar to union work. (Ref. 2, p. 78)

For this reason, and also because the use of laborers on less-skilled material-handling and maintenance tasks (indirect labor) is not different between union and nonunion firms, in the largest heavy construction projects nonunion firms are likely to hire a few more skilled personnel as supervisors instead of workers, a few less-skilled workers for use as workers, and $5 \%$, or 
at the most $10 \%$, more relatively unskilled laborers. It is unlikely that productivity differences because of this slightly different organizational form could be confidently attributed to the benefit of either sector.

\subsection{MANAGERIAL FREEDOM}

Contractors in the nonunion sector of the construction industry enjoy a formally uncontested right to make mariagerial decisions, a right that in the union sector is always subject to union vigilance to protect previously negotiated worker rights and privileges. This uncontested managerial right has been used to force production changes, at least in some sectors of the industry, that quite possibly have had the effect of increased labor productivity. In the heavy construction sector, however, management practices do not seem to differ substantially between nonunion and union firms. Whether this is because unions have allowed substantial modifications of work practices by their contractors, in reaction to the open-shop threat, or whether this is because traditional union practices are more rational and efficient for this type of construction is difficult to determine. But it is hard to see how this managerial freedom could have resulted in nonunion productivity improvements in the heavy construction sector, given that actual management practices continue to be so substantially similar.

\subsection{DIFFERENCE IN LEVELS OF WORKER SKILLS}

Unions claim that their workers are better skilled and able to perform a wider variety of tasks without the need to call on supervisory staff for either further training or direction in how to do their jobs. Basically, this claim is uncontested by nonunion contractors, who respond instead that rarely utilized skills are irrelevant to production, contributing nothing to productivity, and that the over-long training program necessary to produce such useless generalists is also nonproductive, serving only to restrict entry into the trades and reinforce the resulting union monopoly. The union argument is not that its workers are better at the specific tasks that are daily performed, but that they are more flexible, capable of handling a wider variety of tasks. This capability of union workers, to the extent it truly exists (which is to say that not all union workers necessarily possess it), may put back into the work organization, as Stinchcombell claims, more flexibility than the union jurisdictional work rules remove. Although this possibility is more likely in large-scale heavy construction, and although it is the single factor that lends most credibility to Allen's findings of much greater union laboi ploduclivity. (29\% greacer, in fact), there is certainly no verified evidence for this (and Allen has so far declined to release the data that would permit replication of his work).

Adding up all the claims and counter-claims, no basis can be found for endorsing either side's claim to productivity advantages. The proper conclusion is not that the factors favoring unionized or nonunionized productivity cancel each other out but that the work differences that are supposed to callse productivity diffferences in fact hardly exist, at least in the heavy-construction sector of the industry. 


\section{HEAVY CONSTRUCTION: PRODUCTIVITY IN ECONOMIC AND REGULATORY CONTEXTS}

Heavy construction productivity is at least partially determined by its context. The most visible aspect of that context, government regulation, is a hotly debated topic within the industry. But much like the debate over union practices, the regulatory impact is probably not as great as the impact of other, less controversial, contextual factors. Among these other contextual factors, none is more important than the general level of construction sector expansion or contraction, with its cyclical consequences of labor scarcity or labor surplus.

\subsection{THE - ECONOMIC CONTEXT}

One might expect that labor productivity would be highest in periods of high construction unemployment. Logically, one might expect that less productive workers would be laid off, and the fear of job loss would more highly motivate those who remained. Actually, however, the effect of the economic context on productivity is precisely the reverse. Productivity is highfest in periods of construction boom, when management faces a labor scarcity and workers face an ample supply of available jobs.

The construction industry has a productivity pattern in full accord with a pattern most common in the economy as a whole. Productivity increases on the upside of the business cycle and decreases on the downside. The most important reason for this is undoubtedly the scarcity of labor during the boom period. Management simply cannot find the number of workers it would ideally like to have in any particular trade, but is able, nevertheless, to get the job done, so labor productivity rises. Likewise, the participant-observation literature (especially Cherry) 7 indicates that workers will drag a job out if they anticipate unemployment when a job is over, or will hurry a job to completion if they foresee good employment opportunities elsewhere. These two factors more than counteract the countervailing tendencies toward the employment of "dregs" and "warm bodies", workers whose labor patterns or personal problems (often alcoholism) would prevent their finding work under anything but optimum economic conditions.

Ihis effect of the economic context on construction labor productivity is the most. probable reason for the continued decline since 1968 of productivity in the construction industry, that is, if the Commerce Department's method of meaouring construetion labor pioduclivily las any validicy at all. (Only the Commerce Department's studies have documented such a decline; Bureau of Labor Statistics field studies have found productivity in specific construction subsectors to have been increasing consistently throughout this period.)

The effects that the economic context are likely to have on labor productivity in synfuels construction projects over the next decade are hard to project. On the one hand, the industry as a whole has suffered repeatedly from economic measures designed to contain inflation. On the other hand, the underlying demand for infrastructural and residental construction is projected to continue rising through the end of this century. More specifically, there is a debate over the flexibility and elasticity of labor supply in the industry. Despite the recurrent contractions in light and residential 
construction in the 1970s, some analysts believe that there has been a continued shortage of heavy construction labor throughout this period (except during the depths of the 1974 crash). Essentially, the debate is between AGC and union representatives, on the one hand, and $A B C$ representatives on the other. The first group subscribes to a formal system of construction labor training, within which many years of specific apprenticeship education is necessary to produce a worker skilled and competent in any of the construction trades. The latter group believes that a large existing pool of experienced and semi-trained construction labor is already available, and that any one of these workers can be trained, if necessary, in any of the more highly skilled specialties within a few weeks or, at most, months.

Systematic evidence to support either position does not exist, and the scattered evidence that does exist is contradictory and hard to evaluate. Taking a broad overview based on a critical review of the literature regarding this debate, the $A B C$ view is probably the more inherently and "objectively" correct position. Experienced construction workers are sufficiently observant of their work sites to perform tasks requiring more skills than those to which they are generally assigned. In informal home building contexts off the job, many workers regularly demonstrate at least minimal competence in trades other than their own. But workers and managements both have so much invested in the organizational forms and divisions of labor that make up the industry's work system that neither workers nor managers attempt to breach them, even on nonunion projects (See Sec. 5). This is the organizational norm of "reciprocal incompetence," by which each trade protects its own position by pretending incompetence at the tasks of others.

At any rate, for reasons suggested in Sec. 7 , synfuels projects located in relatively isolated rural areas are likely to face a shortage of skilled labor, almost no matter what else is happening to the economy of the construction industry in the larger regional or national context.

\subsection{THE REGULATORY CONTEXT}

"Excessive government regulation" would undoubtedly lower productivity, if it could be objectively determined that such regulation was, indeed, "excessive," but a number of issues make the effect of regulation on productivity harder to analyze than it might first appear. The issue of regulation is a salient one for people in the industry, and everyone in the private sector who was interviewed spontaneously raised this issue as an important variable likely to affect productivity in synfuels construction. Many of the incerviewees' criticisms, however, are technically irrelevant, since they depend on a very general conceptualization of productivity (See Sec. 3). To most managers and union representatives in the construction industry, productivity refers simply to speed and effectiveness in "getting the job done." Using this very broad definition, they condemn any regulation that tightens quality control, narrows building codes, or raises environmental protection standards. Applying the technical definition of labor productivity used in this report, however, such regulation increases not only the amount of labor time nececsary but aloo the valuc and social utility of the product. The impact of this type of regulation on labor productivity, therefore, cannot simply be asserted or even logically determined, but must be empirically measured in each case. On the other hand, health and safety regulations that 
affect the construction work process (as opposed to the resulting product) do undoubtedly reduce labor productivity. Those who impose new regulations in this area do so on the basis of a value judgement that the protection of construction workers is a goal to be pursued, even if it results in a decrease of labor productivity. Likewise, equal opportunity regulation is also based on the judgement that ending job discrimination is worth any temporary negative impact on productivity that might result from a higher proportion of less experienced workers on the job. Government regulations in the fields of occupational health and safety or equal employment opportunity probably do have an actual negative impact, at least in the short run, on labor productivity; but such impacts were presumably foreseen by policy makers who determine that the social benefits of regulation in these two areas outweighed the productivity costs.

But the interviewees, like their trade publications, emphasize regulatory inefficiency in their arguments about the negative impact of government regulation on construction labor productivity. Once again, those interviewed were referring specifically to the state of regulatory confusion in the nuclear power plant construction field. As discussed in. Sec. 4, dilatory or inefficient regulation undoubtedly has a strongly negative impact on productivity, because of the extra direct labor that is required, because of the extra indirect labor that must now document or negotiate compliance, and because of the demoralization that results from missed deadlines and repeated delays. However, every regulated industry believes and proclaims that it is the victim of inefficient and unnecessary regulations, so such claims are hard to assess without findings from specific evaluation research.

There can be no doubt that regulation of the nuclear power construction industry has, in fact, been confused, or that labor productivity has, in fact, been very significantly lowered as a result. But such regulatory confusion is not the mere result of bureaucractic bungling, but of rapid changes in the public and expert perceptions of the level of safety standards that seem necessary and appropriate. As a relatively new program whose intended and unintended consequences are still the subject of contentious debate, the synfuels program is also likely tn experience fluctuationo in public and expert opinion about the kind and degree of regulation that should be necessary. As a result either of the industry's experience with Equal Employment Office (EEO) and Occupational Health and Safety Administration (OSHA) regulations, or as a result of the nuclear construction experience, or, more likely, as a result of the general ideological climate that has developed in response to these experiences, every construction industry interviewee expressed a doubt--stated often with frank cynicism--about the likelihood of avoiding regulatory confusion and delay on synfuels construction projects. All expected that labor productivity, at least in their broad definition of the term, on these projects would be quite low, mostly as a result of the extent of government oversight on these projects. The specific intent of the enabling legislation to minimize such delays was viewed as unlikely to succeed in preventing regulatory complications and delays. 


\section{POPULATION - CHARACTERISTICS AND REGIONAL DIFFERENCES IN HEAVY CONSTRUCTION PRODUCTIVITY}

Both for those inside the industry and those outside, regional differences in heavy construction labor productivity are generally believed to be great, but these differences are difficult to pin down, either conceptually or empirically, due largely to the absence of an adequate standard measure of construction productivity. Most of the apparent differences in regional productivity are attributed by economists to differences in the nature of the output rather than actual differences in the productivity of labor, technically defined. So, for instance, regional differences in the product mix probably account for some large part of the observed differences in labor input/output ratios. Very few types of heavy construction projects are nationally distributed. All are built the way they are, where they are, as a result of regional differences in such factors as economic sector concentrations, natural resources, availability of building materials, climate, land values, population density or market size, and availability of commercial infrastructural. Architects and engineers take such differences into account when designing their projects, and the resulting projects are so different that it is hard to compare them meaningfully. This product-mix problem is simply a specific variant of the quality-deflators problem described in Sec. 2. A second factor that affects both the nature of the output and the labor input required is the cost of available (e.g., cleared or appropriately zoned) land.

In addition to these differences in output, a major source of regional variation in labor productivity is probably a result of regional differences in the cost and sophistication of the technology applied to the project in the form of capital equipment. All of the factors mentioned above affect technological decisions, as do wage rates and total labor costs, so that the technology that is most rational in one region may be less rational for a similar project located elsewhere. Such technological choices obviously could have a very great impact on labor productivity.

But none of these differences either in output or technology are very likely to affect labor productivity as conceptualized for the purposes of this study, since it is assumed that synfuels plant design and construction technology are relatively fixed, regardless of the site finally chosen.

However, after these very important sources of regional differentiation in productivity have been factored out, there remain a few factors that are likely to have a significant impact on productivity. Among these are regional differences in the value systems or "work ethics" of the construction labor force, differences in formal union work rules or informal (union or nonunion) work norms, and the differences in weather. According to the interviews, work norms vary widely from region to region in local light construction, but much less so in large-scale heavy construction. Also, the informal local traditions that are largely responsible for these differences in work norms do not necessarily vary in a uniform direction. In other words, there iś at least some tendency for the work norm variations in the different trades to cancel each other out. Such trade-by-trade differences in work norms, moreover, are different from the more general regional differences in the culture of work ("work ethics") so that extensive local ethnographic research would be required before such comparisons could be made. 
Not only informal norms, but also formal union work rules vary from region to region. It is at least possible, however, that such forms of work rule differences actually have little impact on labor productivity, since Bourdin and Levitt found no significant differences in labor practices either among the eight cities in their nationwide sample or even between union and nonunion contractors.2 According to the union representatives interviewed, however, there is considerable variation both in the content of work rules and the extent to which they are enforced among the various locals within a national union. But these variations, dependent as they are on local union "politics" and traditions, may not vary in the same way from trade to trade. Within each union, national union representatives believe they know which locals are likely to have the most productive workers, that is, accepting their assumption thal workers who belong to the more "reasonable and cooperative" locals are likely to be more productive. Moreover, the union representatives believe that such variation is likely to be systematic and not the random result of local histories, because locals are more likely to be "reasonable and cooperative" in areas where nonunion general contractors have managed to make signiflcant inroads into union labor's traditional domination of the heaviest construction projects.

Such differences in local norms and union rules are at least partially reflected in standardized construction labor-time norms per task of commercial construction. Such figures are available from sources such as Cuthries, published for the benefit of construction production engineers. Summed total differences in regional productivity for a particular project could possibly be calculated from such sources, but only by a person with the knowledge of processing and construction engineering necessary to "task out" a synfuels project.

To check the feasibility of such an approach, two management officials were questioned about their firm's method of ueing such manuals of construction engineering standards. Both characterized such mallual-based calculations as raw data input, the starting point that each firm uses to make a variety of subsequent adjustments (for experience,with the particular subcontractors, the c1ient, the architectural engineers, the unions, the local building code regulatory agencies; or for the likelihood of unanticipated difficulties regarding site preparation, materials supplies, or degign defects). An adjustment is also made on the basis of the firm's general experience in the region (in effect, a system-integration factor, separate from each of the distinct factors mentioned above). All these adjustments are more or less closely held proprietary information, at least unavailable to this researcher for public dissemination in a government=oponanred iuport.

Everyone interviewed believes that regional differences in weather and in "work ethics" also affect productivity in heavy construction. However, industry insiders believe that weather is not as big a factor as it once used to be or as analysts outside the industry still believe it is. Everybody interviewed also believes that productivity in urban areas is significantly lower than elsewhere. The reasons they give for this assessment include references to the nature of the urban construction project output, reasons that were referred to and discounted earlier, and references to the greater labor relations contention and resulting work cynicism in urban areas. In 
other words, those interviewed believe that urban workers are less likely to have a sustained "work ethic", commitment to their jobs than workers in other areas.

Summing up the consequences of all these factors, it, is probable that labor productivity, in the technically valid sense of this study's definition, is highest in sun belt areas where the urban population density is lowest and the competition between union and nonunion contractors is greatest. Speaking very roughly, the regions most likely to meet these various criteria for higher construction labor productivity include Basic Economic Areas 20-51, 117-146, and 161-163.

But even though it is possible to arrive at rough estimates of areas where labor productivity is probably higher than elsewhere, there is not enough information either to verify these area identifications or to estimate the quantity of the productivity difference. It would be unwise to attempt to adjust the output of computerized project impact models (such as Argonne's SEAM) to take these hypothesized regional variations into account. All experts in the field of labor productivity measurement advised against attempting such an adjustment. William Hahn, originator of the Construction Labor Demand System model, and the expert probably most qualified to give advice on this issue, was the most adamant in his opposition to such an attempt, stating in an interview, "You are certain to introduce more error than you will eliminate." Hahn's model, by the way, assumes that construction labor productivity has varied neither among regions nor over the years since the model was originally developed. 
8 PRODUCTIVITY IN BOOM TOWN CONSTRUCTION SITES

Largely as a result of various impact and evaluation studies of western coal and power genertion projects, which were among the earliest energy development projects in the present era of OPEC-induced energy concern, a considerable technical literature is available on "boom town effects," the consequences of very rapid, resource-based economic development in small, previously rural communities. The principal focus of this literature is on the consequences for the community, but these community consequences feed back onto the project itself, and the literature has often, therefore, addressed issues of the quality of 1 ife of the project labor force to a greater extent than the issue of its productivicy.

Although the widespread concern over boom town effects is relatively new, the boom town phenomenon itself is as old as the heavy construction Industry. The higtory in this sountry goes back at least to the Irish and Chinese labor camps that built the canals and railiuads to tranoform the American economy in the early 19th century; the world's history of boom town heavy construction goes back past China's Great Wall and the Egyptian pyramids.

Except for the subway systems, utility inotallations, and skyscraper projects of the urban metropolis, heavy construction projects in the United States have always been boom town projects. Every construction trade had its migratory "boomers" who followed these projects from dam to dam and highway to highway. The boomer lifestyle is always unorthodox, although unorthodox in the traditional way of all-male crews away from home. Traditionally, youthful beginners in any trade tended to work as boomers at least for a while, but, also traditionally, most such youths preferred to settle down to family and community life whenever that option was economically feasible. Conditions of life in the boomer camps were sufficiently bad to function as constant negative incentives, "push factors" sending all who were able back to a more stable family and community-based lifestyle. In the construction trades, boomers were normatively depreciated, either as persons with unstable personalities unable to fit into society outside the labor camps or as persons whose workmanship was too poor to find work elsewhere. Although there have always been colorfully honored exceptions, boomer craftsmen have always been considered less skilled and less productive than their counterparts elsewhere.

This diccussion of hnnmer life in the construction trades has been an historical, past-tense description because the long period of cullstruction prosperity prior to 1968 eliminated the boomer population almost entirely, enabling all who so desired to find work within commuting distance of a permanent home base. Older union of ficials today refer to the present generation of construction workers as "spoiled," sufficiently cushioned by unemployment compensation so that they seldom have to migrate to boom town projects no matter how depressed their local construction economy. Their membership's new reluctance to move causes problems for national-level union officials at least as great as the problems caused for contractor management, since the union officials must help their small-town locals find the labor supply that these boom town projects require. 
The present difficulties in attracting skilled labor to boom town projects affects labor productivity on those projects in several different ways. On the one hand, the chronic scarcity of labor thwarts management's efforts to overhire and underutilize their skilled labor force; on the other hand, only the less-productive or less-experienced workers can be induced to move to this site. These two factors probably counterbalance each other, but all of the other factors consistently tend to lower boom-town labor productivity. The turnover rate among skilled workers on such projects is always abnormally high, as worker after worker is enabled to go home, either through the accumulation of cash from the boomer job or through the renewed availability of jobs in the hometown area. Since construction projects are so unique, a period of time is needed to get to know the ropes of each new site, even for experienced workers; the higher the turnover rate, the higher the proportion of the work force still involved in that less productive period of familiarization

To attract skilled workers to boom town sites, and even more important to retain them once they are there, contractors resort to two principal inducement techniques, both of which further lower labor productivity on the site. One inducement is to introduce the "7-10" system (that is, 7 days a week, 10 hours a day) which allows workers enough overtime to triple or even quadruple the basic union wage. Contractors interviewed believed that workers on such a system produced no more in their 70 hour week than they would normally produce in 40 hours; union representatives disputed this, saying that 45 to 50 hours would be a fairer estimate. In either case, there is no question that the 7-10 system very dramatically lowers the productivity ratio of output per labor time input.

Such extraordinarily high wages are necessary, partially because contemporary boom town workers, unlike the boomer of the past, must maintain two households, one with the family at home and the other at the boom town site, and partially because the costs of boom town living are so artificially inflated as to be prohibitively expensive for a construction worker with a "normal" 40-hour week.

A further step in attracting and retaining the skilled work force has become increasingly necessary for the contractors. On all very large projects, with projected construction duration of 10 years or sometimes even more, contractors find that they must themselves undertake the provision of necessary residential, commercial, and recreational facilities for their workers. A national contractor can arrange for these facilities to be built to temporary or portable designs that can be recycled for future use in other projects, something that lucal entrepencuro cannot do. Morenver, the contractor need not charge rents or fees sufficiently high to pay back the investment almost immediately, as local entrepeneurs must. As a result, the contractor can provide these facilities to the work force at rates much lower than local entrepeneurs. This is a considerable improvement in the boom town worker's life situation, one that makes it much more feasible to maintain two households for an extended period of time or to move the rest of the family to the now more liveable conditions at the boom town site. On the largest projects, according to both management and union representatives, migratory construction workers have recently come to expect such affordable amenities. A contractor who does not arrange for the provisions of these amenities will probably he unable to attract a sufficient skilled labor force under any circumstances short of a major nationwide recession. 
To provide such facilities, a series of ancillary construction projects during the earliest phase of the project construction becomes necessary. In effect, a contractor must assume as part of direct project costs the provision of residential; commercial, recreational, and even transport/ communicational facilities that otherwise would have been provided by local independent entrepeneurs. In other words, economic activity that previously would be classified as part of the basic project's multiplier effect is incorporated into the basic project itself.

Whatever method of inducement the contractor offers, boom town conditions tend to lower the productivity of the labor force in truly dramatic proportions. Most of the increased labor time is systematically absurbed in relacively unproductive overtime work. But the direct provision of labor force accommodations must take place in the earliest possible slage of the construction project, causing a significant increase in the work force during that initial construction phase. 


\section{REFERENCES}

1. Allen, S.G., Absenteeism in the Labor Market, doctoral dissertation, Harvard Business School (1978).

2. Bourdin, C.M., and R.E. Levitt, A Comparison of Wages and Labor Management Practices in Union and Non Union Construction, HUD R 78-10, Pub. No. 598 (June 1, 1978).

3. Dexter, L.A., Elite and Specialized Interviewing, Northwestern University Press, Evanston, Illinois (1970).

4. Ruch, W.A., and J.C. Hershauer, Factors Affecting Worker Productivity, Arizona Bureau of Business and Economic Research (1974).

5. Katzell, R.A., et al, Work Productivity, and Job Satisfaction, New York University, New York (1975).

6. Fabricant, S., A Primer on Productivity, Random House, New York (1969).

7. Cherry, M.S., On High Steel, Ballantine Books, New York (1974).

8. Lasson, K., The Workers, Bantam Books, New York (1971).

9. LeMasters, E.E., Blue-Collar Amistocrats, The University of Wisconsin Press, Wiscons in (1975).

10. Mackenzie, G., The Aristocracy of Labor: The Position of Skilled Craftsmen in American Class Structure, Cambridge University Press, London (1973).

11. Stinchcombe, A., Bureaucratic and Craft Administration of Production: $A$ Comparative Study, Administration Science Quarterly, 4:168-87 (1959): 


\section{BIBLIOGRAPHY}

Alderfer, C.P., Existence, Relatedness and Crowth: Human Needs in Organizational Settings, The Free Press, New York (1972).

Blauner, R., Alienation and Freedom, University of Chicago Press, Chicago (1964).

Bryant, C.D., The Social Dimensions of Work, Prentice-Hall, Inc., New Jersey (1972).

Centers, R.S., and D.E. Bugento, Intrinsic and Extrinsic Job Motivation Among Different Segments of the Working Population, Journal of Applied Psychology, $50: 193-200(1966)$.

Dalton, Melvil1, Unofficial Unien-Management ReZations, American Sociological Revich, PP. GG1-669 (Üctōber 1950).

Dowling, W.F. and L.R. Sayles, How Managers Motivate: The Imperatives of Supervision, McGraw-Hill, New York (1971).

Dubin, R., et al., Leadership and Productivity, Chandler, San Francisco (1965).

Dunlop, J.T., The Industrial Relation System in Construction, in Arnold

Weber, The Structure of Collective Bargaining, Free Press, New York (1961).

Earnings and Other Characteristics of Organized Workers, BLS Report 556 (May 1977).

Ecstein, A.J., and D.M. Heinen A Review of Finergy Polioy with Farticular Reserence to Employment and Manpower Analysis, Employment and Training Administration, U.S. Dept. of Labor.

Fein, M., Motivation For Work, American Institute of Industrial Engineers, New York (1971).

Fein, M., Fuliunal Approaches to Raising Productivity, American Institute of Industrial Engineers, Norcross, Georgia (1974).

Fuchs, V.R., and J.A. Wilburn, Productivity Diferences Within the Services Sector, National Bureau of Economic Research, New Vork (1971).

Fuchs, V.R., ed., Production and Productivity in the Service Industries, Columbia University Press, New York (1975).

Glaser, B.G., The Patsy and the Subcontractor: A Study of Expert-Layman Relationship, The Sociology Press, Mill Valley, Calif. (1972).

Glaser, E.M., Improving the Quality of Work Life... And in the Process, Improving Productivity, Human' Interaction Research Institute, Los Angeles (1973). 


\section{BIBLIOGRAPHY (Cont'd)}

Gold, Bela, Foundations of Productivity Analysis, Pittsburg: The University of Pittsburg Press (1955).

Goldthorpe, J.H., et al. The Affluent Worker: Industrial Attitudes and Behavior, Cambridge University, Press, Cambridge, England (1968).

Haber, W., Industrial Relations in the Building. Industry, 2nd Ed. Arco, New York (1971).

Haber, W., and H.S. Levinger, Labor Relations and Productivity in The Building Trades, University of Michigan Press, Ann Arbor (1956).

Henle, P., Economic Effects: Reviewing the Evidence, In J. Rosow (ed.), The Worker and the Job, Prentice-Hall, Englewood Cliffs, N.J. (1974).

Hollander, S., The Sources of Increased Efficiency, M.I.T Press, Cambridge, Mass. (1965).

Jorgenson, D.W. and Z. Griliches, The Explanation of Productivity Change, Review of Economic. Studies, (1967).

Kahn, R.L., Productivity and Job Satisfaction, Personnel Psychology $13: 275-$ 287 (1960).

Kendrick, J.W., Postwar Productivity Trends in the United States, 19481969, National Bureau of Economic Research, New York (1973).

Kendrick, J.W. Understanding Productivity, The Johns Hopkins University Press, Baltimore (1977).

Kusterer, K.C., Know-How on the Job: Westview Press, Boulder, Colorado (1978).

Levitan, S.A. and W:B. Johnston, Work Is Here to Stay, Alas; Olympus, Salt Lake City (1973).

Mathewson, S.B., Restriction of Output Among Unorganized Workers, Viking, New York (1931):

Mil1s, D.Q., Industrial Relations and Manpower in Construction, Cambridge University Press, Cambridge (1972).

Nadiri, M.I., Some Approaches to the Theory and Measurement of Total Factor Productivity: A Survey, Journal of Economic Literature, 8(4) (December 1970).

National Productivity Comission, Measuring Productivity in the Construction Industry (1972). 
Nordlund, W.J., and J. Mullford, Estimating Employment Potential in U.S. Energy Industries, MLR, 101 (5):10-13 (May 1978).

Northrump, H.R. and H.G. Foster, Open Shop Construction, University of Pennsylvania Press, Philadelpha (1975).

Patchen, M., Participation, Achievement, and Involvement on the Job, PrenticeHall, Englewood Cliffs, N.J. (1970). $\checkmark$ Persowick, V.A., Industry Output and Employment: BLS - Projection to 1990 MLR, 102 (5): 3-14 (April 1979).

Report of a Special Task Force to the Secretary of Health, Education and Welfare, Work In America, The MIT Press, Cambridge, Mass. (1972).

Robinson J.P., R. Athansaiou, and K.B. Head, Measures of Occupational Attitudes and Occupational Characteristics, Institute For Social Research, University of Michigan, Ann Arbor, Michigan (1969).

Rosenblatt, 0. and E.A. Suchman, Blue-Collar Attitudes and Information Toward Health and Illness. In A.B. Shostak and W. Gomberg (eds.), Blue-Collar World: Studies of the American Worker, Prentice-Hal1, Englewood Cliffs, N.J. (1964).

Rosow, J.M., ed., The Worker and the Job, Prentice-Hall, Englewood Cliffs, N.J. (1974).

Rothe, H., Output Rates comong Welders: Productivity and Consistency System. Journal. of Applied Psychology, 54:549-551 (1970).

Roy, D., Quota Restrictions and Goldbricking in a Machine Shop, American Journal of Sociology $57: 427-442^{\prime}$ (1952).

Rush, H.M.F., Job Design For Motivation, The Conference Board, New York (1971)' Sayles, L.R., Behavior of Industrial Work Croups, Wiley, New York (1958).

Shepard, J.M., Functional Specialization, Alienation and Job Satisfaction, Industrial and Labor Relations Review, 23:207-219 (1970).

Shostak, A.B., Blue Collar Life, Random House, New York (1969).

Slocum, Walter L., Occupational Careers, Aldine Publishing Co., Chicago (19.74).

Strauss, George: Control by Membership in Building Trade Unions, American Journal of Sociology, 61(6): 527-535 (1956):

Tausky, Curt, Work Organizations, F.E. Peacock Publishers, Inc., Illinois (1970).

Taylor, J.C., et al.: The Quality of Working Life: An Annotated Bibliography, University of California at Los Angeles, (1973). 


\section{BIBLIOGRAPHY (Cont'd)}

Tripp, L. (ed.), Productivity: A Social and Economic Analysis, Industrial Relations Research Association (1951).

U.S. Dept. of Energy, Creating Jobs Through Energy Policy, DOE/PE-0013 (July 1979).

Vough, Clair F., Productivity, AMACOM, New York (1979).

Wedderburn, D. and R. Crampton, Workers Attitudes and Technology, Cambridge University Press, London (1972).

Whyte, Williams F., Men at Work, Irwin, Homewood, I11. (1961).

Zalenznik, A., C.R. Christensen, and F.J. Roethlisberger, The Motivation, Productivity, and Satisfaction of Workers: A Prediction Study, Harvard University Graduate. School of Business Administration, Boston (1958). 


\section{ACKNOWLEDGMENTS}

This study was conducted as part of an Urban and Community Impact Analysis (UCIA) of Synthetic Fuels, performed for the Regional Impacts Division of the Department of Energy (DOE) Office of Environmental Assessments. F.J. Hinkle was the DOE project officer for the larger UCIA study. D. Wernette of the Economics and Social Sciences Section, Integrated Assessments and Policy Evaluations Group, of the Energy and Environmental Systems Division was the UCIA principal investigator at Argonne National Laboratory: The support of these individuals and organizations, as well as the efforts and cooperation of the typists, editors, and of course interviewees, is gratefully acknowledged. The author also thanks the following reviewers for their helptul comments: $M$, Cantor of American University;'P. Goldman of the University of Oregon; and $W$. Schreiver of the University of Tennessee. 
Distribution for ANL/AA-24

Internal:

S.W. Ballou

M.J. Bragen

D.A. Brodnick

A.D. Brunner

E.J. Croke

A.R. Evans.

P.J. Grogan

L.J. Habegger

D.A. Hanson

L.G: Hill

Y.L. Klein

C.M. Macal

K.S. Maca 1

W.E. Massey

B. Mayo (10)

D.P. McMillen

T.L. McNeil (2)
B.A. Payne

J.J. Roberts

D.J. Santini

W.K. Sinclair

K.K. Smeltzer

D.W. South

T.G. Surles.

E.A. Tanzman

M.W. Tisue

D.R. Wernette (25)

R.G. Whitfield

R.C. Winter

T.D. Wolsko

F.R. Wyant

ANL Contract Copy

ANL Libraries

TIS Files (6)

\section{Externa1:}

DOE-TIC, for distribution per UC-90j (230)

Manager, Chicago Operations and Regional office, DOE

Chief, Dffice of Patent Counsel, DOE-CORO

President, Argonne Universities Association

Energy and Environmental Systems Division Review Committee:

E.E. Angino, University of Kansas

E.N. Castle, Resources for the Future, Inc.

R.L. Clodius, National Assn. of State Universities and Land Grant Colleges

B.A. Egan, Environmental Research and Technology, Inc.

W.W. Hogan, Harvard Uiversity

W.N. Poundstone, Consolidation Coal Company

L.H. Roddis, Jr., Charleston, S.C.

J.J. Stukel, University of Illinois, Urbana

J.J. Wortman, North Carolina State University

T.E. Baldwin, Frederic R. Harris, Inc., Lake Success, N.Y.

R. Ball, U.S. Department of Energy, Washington, D.C.

M.A. Beckwith, Battelle Pacific Northwest Laboratories, Richland, Wash.

L. Bender, Montana State University, Bozeman

L. Blair, Oak Ridge Associated Universities, Oak Ridge, Tenn.

D. Boyce, University of Illinois, Urbana

B. Braid, Oak Ridge National Laboratory

C. Bullard, Office of Technology Àssessment, U.S. Congress, Washington, D.C.

E. Burton, U.S. Department of Energy, Washington, D.C.

M. Cantor, American University, Washingtor, D.C.

C. Cavanaugh, Stone and Webster, Denver

J. Clark, NE Midwest Congressional Coalition, Washington, D.C.

W. Clark, HUD-Office of Planning, Washington, D.C.

C. Cluett, Battelle Human Affairs Research Centers, Seattle 
T. Cochran, Northeast-Midwest Institute, Washington, D.C.

R. Cole, University of Michigan, Ann Arbor

J. Coleman, U.S. Department of Energy, Washington, D.C.

A.R. Cruz, U.S. Department of Labor, Washington, D.C.

G. Daneke, University of Arizona, Tucson

R. Davis, Oak Ridge National Laboratory

J. Dean, Bureau of Land Management, Denver

G.R. Deveny, Tennessee Valley Authority, Knoxville

T. Donville, Mesa County Health Department, Grand Junction, Colo.

E.J. Doyle, Jr., Doyle Associates, Inc., Greenwich, Conn.

C.B. Ellis, State of Wyoming, Cheyenne

B. Fjeldsted, University of Utah, Salt Lake City

A. Ford, Los Alamos Scientific Laboratory

M.B. Gentleman, Lt. Governors office, State of Massachusetts, Boston

J.H. Gibbons, Office of Technology Assessment, U.S. Congress, Washington, D.C.

J. Gilchrist, Montana State University, Bozeman

P. Goldman, University of Oregon, Eugene

J. Greenberg, Econ, Inc., Princeton, N.J.

W. Hahn, U.S. Department of Labor, Washington, D.C.

E. Harris, State Planning Coordinators Office, State of Wyoming, Cheyenne

T. Harris, U.S. Department of Energy, Washington, C.D.

D. Hessel, Pacific Northwest Laboratories, Seattle

F.J. Hinkle, U.S. Department of Energy, Washington, D.C.

L.J. Hoover, Energy Impact Associates, Pittsburgh

C. Hotchkiss, Cornell University, Binghamton, N.Y.

P: House, U.S. Department of Energy, Washington, D.C.

K. Hughes, Joint Economic Committee, Subcommittee on Energy,

U.S. Senate, Washingtion, D.C.

J. Jaksch, Los Alamos Scientific Laboratory

P. Kacser, U.S. Department of Energy, Germantown, Md.

D.E. Kash, U.S. Geological Survey, Reston, Va.

J.S. Kim, Construction Manpower Demand System, Knoxville

P. Kiner, Department of Admin. \& Fiscal Control, State of Wyoming, Cheyenne

G. Krohm, Div. of State Planning \& Energy. State of Wisconsin, Madison

K.C. Kusterer, American University, Washington, D.C. (25)

J.E. Lamson, Institute of Gas Technology, Chicago

D.C. Larson, Western Interstate Energy Board, Denver

G. Leighton, U.S. Department of Energy, Washington, D.C.

L. Leistritz, North Dakota State University, Fargo

R. Lohrding, Los Alamos Scientific Laboratory

C. Mangeng, Los Alamos Scientific Laboratory

L. Marke1, Institute for Energy Analysis, Oak Ridge

R. Matheny, U.S. Department of Energy, Washington, D.C.

J.J. McSweeny, Collieries Management Corporation, Philadelphia

M. Mendis, The MITRE Corporation, McLean, Va.

P. Meier, Brookhaven National Laboratory

J. Metzger, Histecon Associates, Little Rock

L. Mims, Illinois Institute of Natural Resources, Chicago

D. Monti, U.S. Department of Energy, Germantown, Md.

D. Parzyck, Oak Ridge National Laboratory

M.L. Payton, Pullman Kellogg, Houston

D. Rapp, Los Alamos Scientific Laboratory

A. Rogers, International Institute for Applied Systems Analysis, Austria

J. Rosenberg, The MITRE Corporation, McLean, Va. 
P.D. Savatsky, Social Assessment Service, Hudson, Mass.

M. Schacter, San Francisco

W.R. Schriver, University of Tennessee, Knoxville

D. Scrimgeour, Synthetic Fuels Report, Denver

N. Seltzer, U.S. Department of Energy, Washington, D.C.

R.G. Sextro, University of California, Berkeley

T. Shillington, Montana State University, Bozeman

R. Shull, U.S. Department of Energy, Germantown, Md.

W. Siri, University of California, Berkeley

T.A. Sladek, Colorado School of Mines Research Institute, Golden

J. Smith, Ohio Wesleyan University, Delaware, Ohio

E.J. Stenehjem, University of Denver

A: Stroup, Los Alamos Scientific Laboratory

M. Tincani, Carslisle Group, Beverly Hills, Calif.

C. Topping, U.S. Department of Energy

R.L. Valeu, Basin Electric Power Cooperative, Bismarck, N.D.

J. Waldo; Johh Short \& Associates, Salt Lake City

R. Webster, Construction Engineering Research Laboratory, Champaign

A. Weinberg, Institute for Energy Analysis, Oak Ridge, Tenn.

T. Williams, U.S. Department of Energy, Washington, D.C.

C. Wolf, University of Illinois, Urbana

J.C. Zuck, Battelle Pacific Northwest Laboratories, Richland, Wash. 